Relations industrielles

Industrial Relations

\title{
European Labor Relations in the 70's, An Overview, Part I, Brussels, Management Counsellors International, 11972, 89 pp.
}

\section{Gérard Dion}

Volume 28, numéro 2, 1973

URI : https://id.erudit.org/iderudit/028410ar

DOI : https://doi.org/10.7202/028410ar

Aller au sommaire du numéro

Éditeur(s)

Département des relations industrielles de l'Université Laval

ISSN

0034-379X (imprimé)

1703-8138 (numérique)

Découvrir la revue

Citer ce compte rendu

Dion, G. (1973). Compte rendu de [European Labor Relations in the 70's, An

Overview, Part I, Brussels, Management Counsellors International, 11972, 89

pp.] Relations industrielles / Industrial Relations, 28(2), 440-440.

https://doi.org/10.7202/028410ar

Tous droits réservés @ Département des relations industrielles de l'Université Laval, 1973
Ce document est protégé par la loi sur le droit d'auteur. L'utilisation des services d'Érudit (y compris la reproduction) est assujettie à sa politique d'utilisation que vous pouvez consulter en ligne.

https://apropos.erudit.org/fr/usagers/politique-dutilisation/ 
such as perception, personality, motivation, attitudes, communication, status, roles, power, leadership and performance.

The approach is particularly interesting since it explains in details the contribution of behavioral scientists, and the practical applications for the supervisor in any kind of human organization whether industrial, commercial, educational, professional or governmental.

The chapters on the manager as a leader, and as a behavioral scientist are valuable to help the supervisor to handle many human problems in his daily work. The author concentrates in the last part of the book on developing a tree-level model which the reader can employ to evaluate the current effectiveness of this organization.

Lawless' book is particularly recommended for employees with little or no knowledge of organizational psychology or sociology, because it provides readers with sound conceptual foundations. Nevertheless, a few chapters would have included practical examples, and this reviewer is surprised to read «... They should treat all research and writing in management and organizational psychology done before 1960 of historical interest only 》 (p. 12) considering that in Lawless' bibliography, $50 \%$ of his 110 references were published before 1960 !

Effective Management is a very good text, superior in many aspects to many «cookbooks» published recently, and would especially be recommended for personnel managers.

Jean LADOUCEUR

European Labor Relations in The 70's, An Overview, Part I, Brussels, Management Counsellors International, 1972, 89 pp.

Cet ouvrage se propose d'indiquer les grandes tendances qui marquèrent les relations professionnelles au cours des années 70 ainsi que de souligner les questions fondamentales qui semblent se poser.

Il comprend cinq chapitres: Les tendances des relations professionnelles dans l'Europe de l'Est; le projet d'une loi des compagnies couvrant toute l'Europe et ses conséquences sur les relations professionnelles; l'attitude des syndicats devant les firmes multinationales; les relations professionnelles multinationales et la menace des firmes multinationales: la participation des travailleurs à la direction: défi et chances.

Préparé par une équipe de spécialistes très compétents en vue de guider surtout les hommes d'affaires, cet ouvrage fournit des informations objectives et essentielles qui sont extrêmement précieuses à tous ceux qu'intéresse le développement des relations professionnelles. On annonce la parution de la seconde partie qui sera consacrée à des monographies sur des pays particuliers.

\section{Gérard DION}

\section{Les coûts et l'efficacité dans les hôpi-} taux canadiens, par R.D. Fraser, Etude spéciale no 13 préparée pour le Conseil économique du Canada, Ottawa, Information Canada, 1972, 157 pp.

Cette étude commanditée par le Conseil économique du Canada avait pour objet d'évaluer les coûts et l'efficacité des hôpitaux canadiens. Après avoir présenté un aperçu chronologique des hôpitaux et des soins hospitaliers au Canada depuis la Seconde Guerre Mondiale, l'auteur établit des comparaisons, à l'échelle provinciale, en matières d'installations hospitalières, de personnel, de coûts et d'utilisation des ressources.

Les résultats de l'étude sont assez limités étant donné la complexité de l'objet de la recherche et la simplicité de la méthode d'analyse utilisée : l'examen de relations linéaires entre divers facteurs ne portant que sur une seule année (1966).

Malgré tout, l'auteur dégage quelques observations assez intéressantes : en effet, il semble qu'un ensemble de forces influent systématiquement sur le niveau des coûts hospitaliers par rapport à la production, et le niveau de la production par rapport aux facteurs de production. De plus, l'auteur rapporte qu'en ce qui a trait à la nature des rapports entre les coûts et la production, il n'existe 